\title{
The Effect of Corporate Strategy to Company Performance
}

\author{
Dr. Cross Ogohi Daniel \\ Departments of Public Administration/Banking and Finance, \\ Nile University of Nigeria, \\ Abuja, Nigeria \\ Email: danielcross [AT] nileuniversity.edu.ng
}

\begin{abstract}
PT. Telekomunikasi Indonesia, Tbk (Telkom) is a state-owned enterprise that serves telecommunication services and network across Indonesia. Telecommunication business is a "legacy" platform of this company; whereas another portfolio business that called "new wave" has, motivate the company to keep making innovation related to digital based product. This confirms Telkom's commitment to increase revenue amid competitive business environment. In 2015, Telkom's management has targeted a growth of 8\%, which is slightly above the market growth. It has "first thing first strategy" to make a sustainable competitive growth in all business units in Telkom. Based on above description, it is thought that it would be beneficial to analyze how the company's cooperates strategy affects the performance of Telkom's business unit. Unit analysis used in this research is 30 business units of Telkom that spread across Indonesia. From the hypothesis test using Partial Least Square (PLS) approach, it was revealed that corporate strategy has a significant effect to improve company performance. The most dominant aspect that reflects corporate strategy is portfolio strategy followed by directional strategy and parenting strategy. As for the company performance variable, profitability dimension is the most reflecting the company performance, followed by sales and market share dimension.
\end{abstract}

Keywords---- Corporate Strategy, Company Performance

\section{INTRODUCTION}

Telkom Group is a telecommunications company that provides telecommunication services and other network services in Indonesia telecommunications and network service. Telkom Group serves more than 160 million of

customers throughout Indonesia with a complete range of telecommunications services that includes fixed wire line and fixed wireless connections, mobile communications, networking and interconnection services and Internet and data communication services.

\subsection{Review}

According to porter "corporate strategy is a strategic platform, or organization capability to cope a business in a different environment with a set of strategic capabilities. Wheelan and Hunger has categorized corporate strategy into Directional Strategy, portfolio analysis, and corporate parenting. There are three types of directional strategies, growth strategy, stability strategy and retrenchment strategy whereas portfolio analysis consists of two different techniques, which are BCG Growth-share matrix and GE Business Screen.

Caldart and Ricart (2006) argue that corporate strategy is a dynamic framework for a company strategy involved three interconnected elements that shape the company strategy itself, which are cognition (identifying success factors), company's initiative strategy and architecture design.

Hubbard \& Beamish (2011) stated "Because corporate strategy is concerned with multi-business, it implies Diversification of business. Diversification may be defined: The entry of a company or business unit into new lines of activity, by either internal business development or acquisition of new business. This may entail changes in its administrative structure, systems, and other management process”. Ireland, Hoskisson, Hitt (2013) also stated that A corporate level strategy specifies actions a firm take to gain a competitive advantage by selecting and managing a group of different businesses competing in different product market. Meanwhile, Nguyen Huu Le Larimo Jorma (2009) said Parent firms' strategies refer to strategic motives, importance, focus, and competitiveness.

Company's performance is a multidimensional measurement of a company that involves several aspects, such as: accounting, economic, human resources organizing, marketing, psychology, sociology, and strategic management (Marr Dan Schiuma, 2003). Vorhies and Morgan (2005) have done an evaluation to company's performance through two important elements, quantitative financial element and qualitative assessment. According to Wheelen and Hunger (2012) business performance can be measured by sales, market share and profitability. 
Table i : Resume Of Previous Research Journal about the Relationship Between Corporate Strategy And Company’s Performance

\begin{tabular}{|c|c|c|c|}
\hline Researcher & $\begin{array}{l}\text { Research } \\
\text { Objectives }\end{array}$ & $\begin{array}{c}\text { Analysis } \\
\text { Unit }\end{array}$ & Resume \\
\hline $\begin{array}{l}\text { Jai Jeen Lee } \\
\text { Corporate } \\
\text { Strategic } \\
\text { Action } \\
\text { Portfolios } \\
\text { And Fimm } \\
\text { Pexfomance } \\
\text { In The US } \\
\text { Telecom } \\
\text { Industry } \\
\text { (1984-2004) } \\
2008\end{array}$ & $\begin{array}{l}\text { Thvestigate } \\
\text { how a fim's } \\
\text { conporate } \\
\text { strategic } \\
\text { action } \\
\text { portfolios. } \\
\text { defined as } \\
\text { bundles of } \\
\text { key conporate } \\
\text { strategic } \\
\text { actions, relate } \\
\text { to } \\
\text { deregulatony } \\
\text { and } \\
\text { technological } \\
\text { changes, and } \\
\text { to furm } \\
\text { perfopmance. }\end{array}$ & $\begin{array}{l}\text { The } \\
\text { USTelecen } \\
\text { Industoy }\end{array}$ & 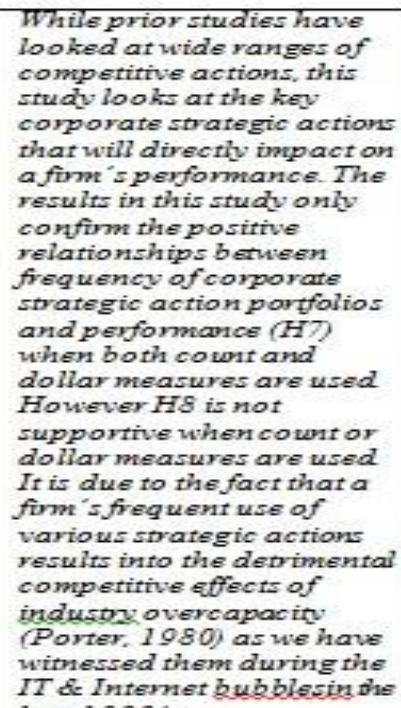 \\
\hline 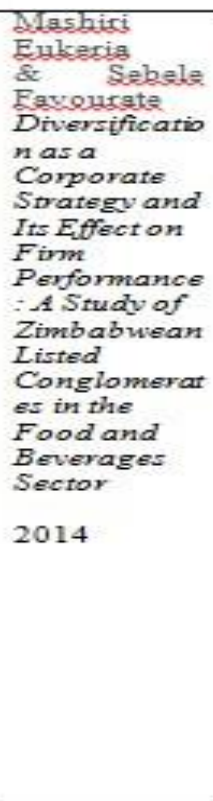 & $\begin{array}{l}\text { Jooked at } \\
\text { diversificatio } \\
\text { n as a } \\
\text { comporate } \\
\text { strategy and } \\
\text { its effecton } \\
\text { firm } \\
\text { perfomance } \\
\text { using } \\
\text { Conglomerate } \\
\text { s in the Food } \\
\text { and } \\
\text { Beverages } \\
\text { Sectorlisted } \\
\text { on the ZSE }\end{array}$ & $\begin{array}{l}\text { The Food E } \\
\text { Beverage } \\
\text { Sectorin } \\
\text { Zimbabwe }\end{array}$ & 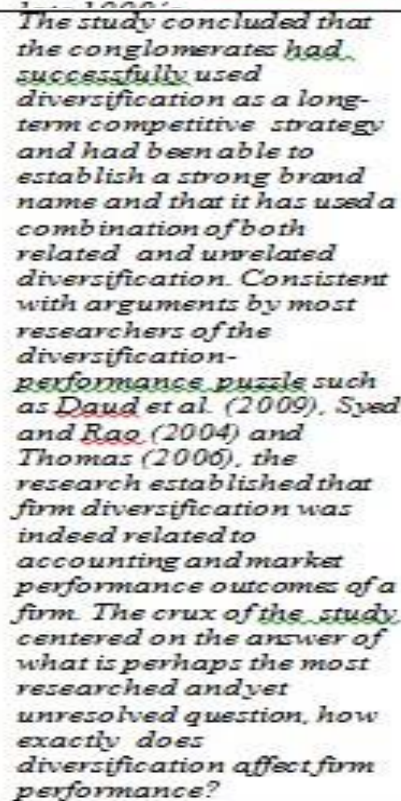 \\
\hline
\end{tabular}

Below is a table of previous research about the relationship between corporate strategy and company's performance. Some of the research above has shown that there is relation or interconnection between corporate strategy and company's performance.

\subsection{Objective}

To reveal the effect of corporate strategy to business unit's performance in PT. Telkom Indonesia

\section{RESEARCH METHOD}

\subsection{The Methods Used}

The nature of this research is descriptive and verifiable. Verificative means the writer want to examine the truth of a hypothesis, which gained through data collection. Where in this research, writer will examine whether a corporate strategy could affect to the company's performance of business units in PT. Telkom Indonesia. Research method used is descriptive survey and explanatory survey. 
Analysis unit here is PT. Telkom Indonesia that has a plans and corporate strategy. Examination units for this research are PT. Telkom's business units across Indonesia. Meanwhile the time horizon used here is a cross sectional, where the research conduct in a one time period on 2014.

\subsection{Sampling Technique}

Population in this research are business units of PT. Telkom Indonesia that spread across Indonesia, with 30 units taken as a research sample.

\subsection{Hypothesis Test}

Refer to the research's objective and also sample limitation, writer using PLS (Partial least Square) analysis to show that corporate strategy can increase company's performance in PT. Telkom Indonesia's business units.

\section{DISCUSSION}

In this part we will discuss the result of this research in verifiable way through hypothesis test using Partial Least Square (PLS). Before the discussion begin, hypothesis will be analyzed with model comparison test result. In PLS, model prediction evaluation is done using two analyses, which are inner model and outer model.

\subsection{Measurement Model}

Measurement model show how is the relation between indicator variable with its latent variable. Measurement model is aimed to analyze indicator validity used to measure each of the research' construct variables. The analysis of measurement model involves reliability values (Conbachs Alpha), square root of average variance extracted (AVE) and composite reliability, if the value of composite reliability $>0,7$, and the value of $\mathrm{AVE} \geq 0,5$, then it will be confirmed that the measurement has fulfill convergent validity (Hair et all, 2010)

Table ii : Reliability

\begin{tabular}{|c|c|c|c|}
\hline Variabel & AVE & $\begin{array}{c}\text { Composite } \\
\text { Reliability }\end{array}$ & $\begin{array}{c}\text { Cronbachs } \\
\text { Alpha }\end{array}$ \\
\hline Company Performance & 0,695 & 0,871 & 0,779 \\
\hline Corporate Strategy & 0,682 & 0,864 & 0,764 \\
\hline
\end{tabular}

Source: Output SmartPLS 2.0 (2014)

From the above table know that Cronbachs Alpha for all variables are $>0,7$; and so does with the Composite Reliability value $>0,7$ and $\mathrm{AVE} \geq 0,5$. It is mean that the measurement model of two latent variables has a consistency and have exactness to measure a construct.

Table iii: Loading Factor Of Research Variable

\begin{tabular}{|l|l|l|l|l|}
\hline Model Pengukuran & $\square$ & Standard Error & $\begin{array}{l}\text { t } \\
\text { Statistics } \\
(|\square / \mathrm{SE}|)\end{array}$ & Outer model \\
\hline X1 <- Corporate Strategy & 0,882 & 0,129 & 6,859 & $\mathrm{X}_{1}=0,882 \mathrm{CS}+\square_{1}$ \\
\hline X2 <- Corporate Strategy & 0,876 & 0,120 & 7,296 & $\mathrm{X}_{2}=0,876 \mathrm{CS}+\square_{2}$ \\
\hline X3 <- Corporate Strategy & 0,708 & 0,115 & 6,174 & $\mathrm{X}_{3}=0,708 \mathrm{CS}+\square_{3}$ \\
\hline Y1 <- Company Performance & 0,859 & 0,142 & 6,030 & $\mathrm{Y}_{1}=0,859 \mathrm{CP}+\varepsilon_{1}$ \\
\hline Y2 <- Company Performance & 0,906 & 0,115 & 7,884 & $\mathrm{Y}_{2}=0,906 \mathrm{CP}+\varepsilon_{2}$ \\
\hline Y3 <- Company Performance & 0,726 & 0,137 & 5,283 & $\mathrm{Y}_{3}=0,726 \mathrm{CP}+\varepsilon_{3}$ \\
\hline
\end{tabular}

The result of measurement model' analysis of each variables shows that all indicators are valid with t count loading factor value bigger that 2.07 ( $\mathrm{t}$ table). The higher loading factors mean good validity level of an indicator to measure a construct. 
$\mathrm{X} 2$ is a most valid indicator to measure Corporate Strategy, while Y2 s a most valid indicator to measure Company Performance.

\subsection{Structure Model Evaluation (Inner Model)}

Structure Model can be evaluated by seeing the $\mathrm{R}^{2}$ value on endogen variable and path coefficient parameter.

Table iv : Structure Model Testing (Inner Model)

\begin{tabular}{|c|c|c|}
\hline Variables & R -Square & Communality \\
\hline Company Performance & 0,162 & 0,695 \\
\hline Corporate Strategy & & 0,682 \\
\hline
\end{tabular}

Table above show that $\mathrm{R}^{2}$ value has an enough criterion, and so does with the communality value (the amount of variant given by a variable to another) that shows higher value. Thus, it can be concluded that research model is supported by empirical condition or fit model.

Picture below show the result of model testing using Smart

Picture 1 : Path Coefficient

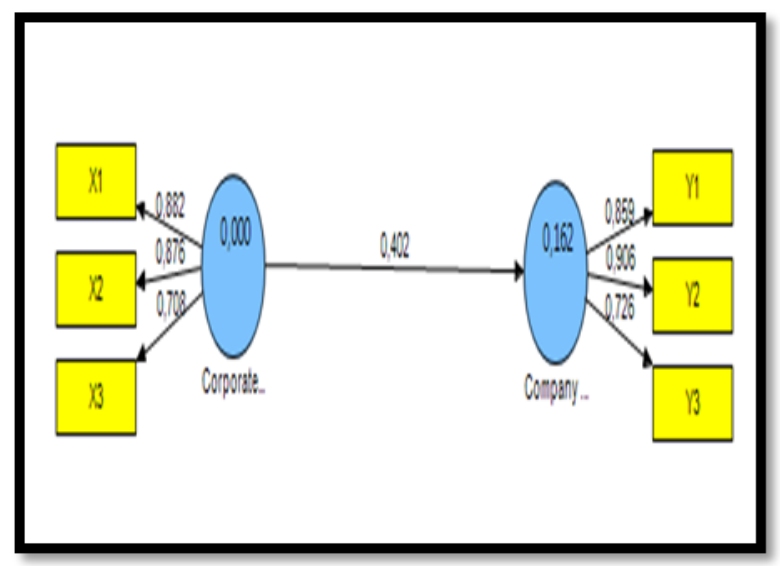

Picture $2: \mathrm{t}$ statistic Structure model for the above diagram is :

$$
\mathrm{CP}=0,402 \mathrm{CS}+\zeta_{1}
$$

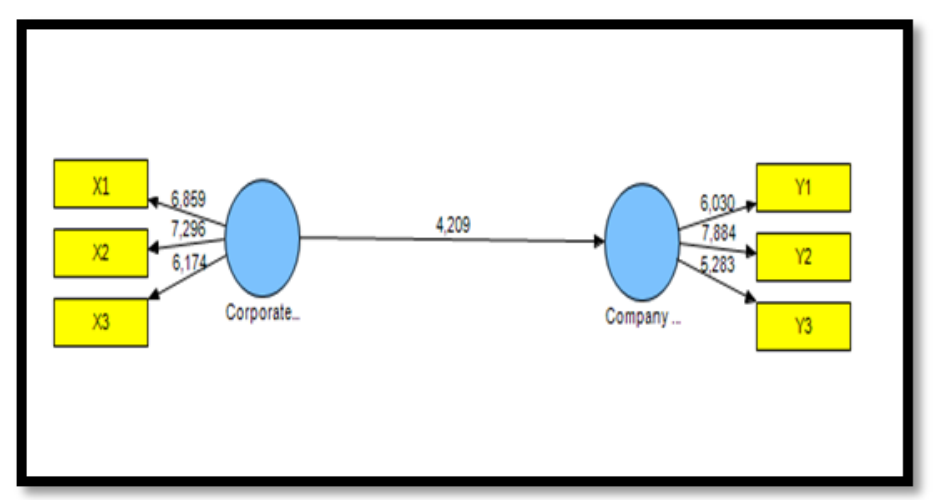

Table v : Hypothesis Test Result 


\begin{tabular}{|c|c|c|c|c|}
\hline $\begin{array}{c}\text { Structure } \\
\text { Models }\end{array}$ & $\square$ & $\begin{array}{c}\text { Standard } \\
\text { Error }\end{array}$ & $t$ count & Description \\
\hline $\begin{array}{c}\text { Corporate } \\
\text { Strategy } \\
\text {-> Company } \\
\text { Performance }\end{array}$ & 0,402 & 0,096 & $4,209 *$ & Significant \\
\hline
\end{tabular}

The test show that the effect of corporate strategy to company performance is significant with t-statistic s higher than 2,07 ( $\mathrm{t}$ table at $\square=0,05$ ); it has affect $16,2 \%$ and the other factors effect rate is $83,8 \%$

From the measurement result show that the portfolio strategy dimension (X2) is the higher contributor dimension to reflect corporate strategy in PT. Telkom Indonesia, followed by directional strategy dimension (X1), and parenting strategy (X3). While for the company's performance variable; company's profitability dimension (Y2) is the most reflecting company performance, followed by sales 9Y1) and market share (Y3).

The result described above revealed that corporate strategy has significant effect to increase business units' performance of PT. Telkom Indonesia. Portfolio strategy that includes the development of competitive strategy implemented by PT. Telkom Indonesia to its business units; and the implementation of business unit development strategy has given higher contribution in reflecting that corporate strategy could support company performance in business units of PT Telkom Indonesia.

Considering the research result, PT. Telkom Indonesia needs to improve portfolio strategy. To make it happens, they will need an operational strategy that involves the improvement of capability to create competitive strategy at its business units; and capability to improve the strategy implementation of its business units.

The development of portfolio strategy could that improved company performance is need to be supported through the directional strategy implementation, through the implementation of growth strategy, alliance strategy, stability strategy; effectiveness strategy and efficiency strategy. In other side, to optimum the performance they also must to improve the implementation of value creation strategy; relationship strategy; strategic planning; financial control; and strategic control

\section{CONCLUSION AND RECOMMENDATION}

Corporate strategy has a significant effect to increase company performance at business units of PT. Telkom Indonesia. The most dominant aspect in reflecting the corporate strategy is portfolio strategy, followed by directional strategy and parenting strategy. Meanwhile, for company performance variable, company's profitability dimension is the most reflecting company performance followed by sales dimension and market share.

\section{a. Practical Recommendation}

Based on the result, recommended that corporate strategy could be used as a basic to improve company performance at business unit of PT. Telkom Indonesia in a sustainable way. Thus, the management of PT. Telkom must consider important aspects below:
a. The improvement of competitive strategy development at its business units
b. The improvement of development strategy at its business units
c. The improvement of growth strategy implementation
d. The improvement of alliance strategy implementation
e. The improvement of stability strategy implementation
f. The improvement of effectiveness strategy implementation
g. The improvement of efficiency strategy implementation
h. The improvement of value creation strategy implementation
i. The improvement of relationship strategy implementation
j. The improvement of strategic planning implementation
$\mathrm{k}$. The improvement of financial control implementation
1. The improvement of strategic control implementation

\section{b. Academics Recommendation}

This research result expected could be a reference for academics to do next research development, and could use these results as a premise to organize a framework. Hopefully, there are more academics people who interest to do the research about corporate strategy, both at PT. Telkom and others state owned companies, with different point of view to enrich management strategic study. 


\section{REFERENCES}

[1] Caldart, Adrian A. \& Ricart, Joan E., 2006 ,Corporate strategy in turbulent environments: Key roles of the corporate level," IESE Research Papers D/623, IESE Business School.

[2] Capron , Laurence , 2013, Cisco's corporate development portfolio: a blend of building, borrowing and buying,Strategy \& Leadership 41.2 : 27-30. http://dx.doi.org/10.1108/10878571311318213

[3] Doise, Michelle Lee. 2008, An integration of corporate culture and strategy: The interrelationships and impact on firm performance, University of Arkansas, Pro Quest, UMI Dissertations Publishing

[4] Eukeria, Mashiri; Favourate, Sebele , 2014, Diversification as a Corporate Strategy and Its Effect on Firm Performance: A Study of Zimbabwean Listed Conglomerates in the Food and Beverages Sector, . International Journal of Economics and Finance 6.5 : 182-195. http://dx.doi.org/10.5539/ijef.v6n5p182

[5] Ferguson, Karen L. ;Reio Jr, Thomas G. , 2010, Human resource management systems and firm performance", The Journal of Management Development 29.5 : 471-494. http://dx.doi.org/10.1108/02621711011039231

[6] Ghalayini, A.M., Noble, J.S. and Crowe, T.J., 1997, An integrated dynamic performance measurement system for improving manufacturing competitiveness, International Journal of Production Economics, Vol. 48, pp. $207-25$. http://dx.doi.org/10.1016/S0925-5273(96)00093-X

[7] González-Benito, J. y González-Benito, O. , 2005:802, Environmental Proactivity and Business Performance: An Empirical Analysis", Omega, Vol. 33, n.1, pp. 1-15. http://dx.doi.org/10.1016/j.omega.2004.03.002

[8] Hubbard G., Beamish P., 2011, Strategic Management - Thinking, Analysis, Action, Pearson Australia, $4^{\text {th }}$ Edition

[9] Ireland , DR, Hoskisson , RE, dan Hitt , MA, 2012, Understanding Business Strategy, 3rd edition, South-Western College

[10] Lee , Jai Joon, 2008, Corporate Strategic Action Portfolios And Firm Performance In The US Telecom Industry (1984-2004), University of Pittsburgh, Pro Quest, UMI Dissertations Publishing

[11] Snedegar, Steven T, 2009, The Amalgamation Of Capabilities And Strategies As Determinants Of Firm Performance: U.S. Telecommunications Industry, Capella University, Pro Quest, UMI Dissertations Publishing

[12] Vorhies, D. W. \& Morgan, N. A. 2005, Benchmarking Marketing Capabilities for Sustainable Competitive Advantage. Journal of Marketing . http://dx.doi.org/10.1509/jmkg.69.1.80.55505

[13] Heelen, Thomas L., \& Hunger, J. David. 2012: Strategic management and business policy: Concepts.13th ed. Pearson/Prentice Hall. 